\title{
The Effect of Total Quality Management Dimensions (Elements) on Financial \& Job Performance "A field study in Sudanese French Bank, Khartoum State - Sudan"
}

\author{
OMER ALI BABIKER ELTAHIR \\ Darb University College- Jazan University-KSA \\ Email: obabiker@jazanu.edu.sa \\ Tel: 00966536691922 \\ NIZAR BEN ABDALLAH \\ Darb University College- Jazan University-KSA \\ Email: nbenabdallah@jazanu.edu.sa \\ Tel: 00966530700813
}

\begin{abstract}
The main aim of this study to declares the effect of total quality management (TQM) dimensions represented by (support and commitment of senior management philosophy of total quality, continuous improvement, education and training for workers, the participation of employees, customer satisfaction)on Financial \& Job Performance in Sudanese French Bank in Khartoum State-Sudan. The problem of the study lies in answering the following key question: What is the effect of total quality management and its dimensions (elements) on job \& financial performance in the Sudanese French Bank? Subsidiary questions have examined the impact of each dimension of the (TQM). The descriptive analytical method was used in this study to collect and analyze data in the applied study. The study population are all workers in Sudanese French Bank, the workers has been selected in Sudanese French Bank- Khartoum State, where the study sample consisted of 120 employees in Sudanese French Bank-Khartoum State from all the levels. Through the study and analysis of the dimensions of Total Quality Management, and its impact on improving financial performance in the Sudanese French Bank, Findings of this study indicate that there is a statistically significant relationship between the overall quality, liquidity ratio, profitability ratio and financial performance elements in the Sudanese French Bank.
\end{abstract}

Keywords: Total Quality Management, TQM dimensions, Financial Performance, Job Performance, Sudanese French Bank.

\section{Introduction}

The current global trend of the top management persons in business organizations has turned into an inevitable necessity in light of the growing fierce competitiveness among organizations to the extent that the very survival of an organization is pending its ability to achieve high levels of strong competiveness. This pushed the top management to assess competiveness strategies and management behaviors with view to improving the performance of organizations towards excellence.

The challenges facing the world today are many and varied, most notably in the scarcity of available resources, the increasing needs of society, the rapid change of events, and the consequent identification of priorities and the effective distribution of what they are available from human and physical resources. (Terturi \& Joeyhan, 2006). 
It is a concept that overlaps with similar concepts like that of the 'Quality Management Systems' laid out in the International Organization for Standardization (ISO 9000 series), which provides world standards for management best practices. TQM principles have determined that individual ownership and pride in workmanship for all departments and employees results in a better product.( Kasim Randeree, Ashish Mahal, Anjli Narwani, 2012).

Quality in the service sector depends on a technical board that tests quality and the purchased quantities, which requires the selection of a certain criterion or certain manufacturing phases of the product to insure the required quality standard, such as depending on the criterion of the product, criterion of the employee or the criterion of manufacturing. Thus, achieving the required standards of quality necessitates the correct selection of those criteria and in pursuance with the activities of the organization (Terziovskim, M. \& Samson, D. (2000).

"Banks are opening up their definition of quality management and considering what their customers expect and experience, rather than just what the bank provides," says Diane Sauter, president of Strategic Solutions, Golden, Colo. "There are a lot of factors that go into total quality that the customer never sees, yet considers important, such as accuracy in processing or up time for ATMs."

The purpose of this study is to study the effect of Total Quality Management (TQM) elements on Sudanese French Bank financial \& job performance. It aims to study and analyze the nature of the relationship between TQM and the possibility of promoting and activating the financial and job performance of Sudanese French Bank.

\section{The Problem and Questions of the Study}

Many organizations of industrial and service industries have taken great responsibility to implement the principles of quality management in all areas of the activities, in order to improve the financial $\&$ job performance and ensure survival in a highly competitive environment. The principles of quality management are keen to improve financial \& job performance, and through the field visits to the reality of the case in commercial banks, it shows that the bank suffers from the low level of banking services and the lack of full understanding of the requirements of the management of solid and firm quality, which reflects negatively on the job \& financial performance of the bank.

The service organizations are currently witnessing a number of changes, the most prominent of which is the growing dependence on advanced technology, the scarcity of basic materials, the growing competitiveness among local and global organizations, in addition to the increasing change in the clients' behavior; the increase in their standards of needs, desires and expectations; and the conversion of luxury needs into basic needs in the life of clients. This study is trying to reach the desired results by answering the following question:

What is the effect of total quality management and its dimensions (elements) on job \& financial performance in the Sudanese French Bank?

And the sub-questions:

- What is the nature of total quality management elements and level in the Sudanese French Bank, Khartoum State-Sudan?

- What is the reality of financial \& Job performance in the Sudanese French Bank?

- Does TQM impact job \& financial performance by improving quality?

- What is the effect of the overall quality elements in improving the reality of financial \& Job performance in the Sudanese French Bank, Khartoum State-Sudan? 


\section{Objectives of the Study}

The main aim of this study to declares the effect of (TQM) on Financial \& Job Performance in Sudanese French Bank in Khartoum State-Sudan. This study aims to achieve the following:

1. Identify and explain the definitions of TQM, concept of total quality management and its importance as modern management methods that may affect the level of financial performance \& job performance in Sudanese French Bank, Khartoum State- Sudan.

2. Identify the relationship between the improvement of job \& financial performance in Sudanese French Bank through total quality management.

3. Knowledge that if total quality management is essential and have any impact to achieve improvement in financial \& job performance in Sudanese French Bank, Khartoum State-Sudan.

4. Recognize the reality of financial \& Job performance in Sudanese French Bank.

5. Survey the effect of TQM on Financial \& Job Performance in Sudanese French Bank, Khartoum StateSudan.

\section{The Importance of the Study}

The importance of study was in the important role played by the banking sector in the economy, but the attention of researchers and scholars is weak in our country, so more researches and studies are required for this field. The quality of service is considered as a rising competitive style, As it is one of the bank's main pillars today to face the fierce competition in the market, as well as one of the most important indicators to attract the customers and meet their needs and desires and raise the awareness of the employees of the bank towards the total quality management and its dimensions.

The study takes its importance from its important variables, where maintaining the quality and speed of achievements, and to highlight the contribution of the overall quality management in improving the financial \& job performance reality. Therefore, the importance of this study lies in followings:

1. Highlight the role of total quality management as a way to improve financial $\&$ job performance.

2. To identify the relationships of total quality management and financial \& job performance.

3. Recognize the reality of financial \& job performance in the Sudanese French Bank.

4. Field importance, in an attempt to provide a scientific basis that could help the study (sample bank) in determining the relationship between total quality management and financial \& job performance.

5. Enrich national and international library with the necessary information about the overall quality management and the financial \& job performance in the Sudanese French Bank - Khartoum State.

\section{Review of Related Literature}

Hilda Ghaleb Madanat, Anis S. Khasawneh, (2017) this research aimed at investigating the impact of implementation of total quality management (TQM) on the effectiveness of human resource management (HRM) practices in the Jordanian banking sector.

Ameen Al-basheer and others (2015), the quality in the service sector is essential to organizations, particularly banking organizations, as it should focus on the concept of total quality management services to improve the quality of services and banking operations and measures the level of financial performance in it. The study examined the relationship analysis and influence between the adoption of the philosophy of total quality management and its impact on improving the financial performance in a leading financial institution in Jordan, Jordan Islamic Bank in Irbid Province.

Abla S.S Tahtamouni \& others (2013), the aim of this study is to analysis the factors affecting Total Quality management (TQM) implementation in Jordanian Commercial Banks. Analysis of variance 
(ANOVA) is conducted to test if there are any statistical evidences of the existence of difference between factors affecting Total Quality management (TQM) implementation in Jordanian Commercial Banks and the independent variables.

Jureviciee \& Skvarciany (2013) conducted to determine the main factors of customer satisfaction on the quality of services provided by commercial banks. A questionnaire was distributed to customers. The researchers identified ten variables: understanding the working environment, mobility, flexibility, communication skills, SME interest, decision making speed, responding to customer needs, awareness, level of expertise, and reliability, the most effective elements influencing customer satisfaction.

Abd Al- Mouty \& Abu Zyeada (2012), the Palestinian commercial banks were found to be applying all the dimensions of TQM except employee participation, and it was noticed that when TQM and time are together, they have a higher effect on job performance in Palestinian banks.

Agrawal \& Shukla, (2012) A Study on Privilege used the analytical approach by collecting data on the study and analyzing it in the automotive sector. The results of the study showed that quality concessions affect the performance of companies and there is positive evidence if companies implement TQM successfully. The results also showed strong performance improvement for units operating with quality concessions in the company. The importance of quality control in correcting the defect of the products before the production of quantities of products that do not meet the specifications.

Jain \& Gupta (2012), aimed at studying the implications of TQM in employee perceptions. The study used the HRM method (or live perception of human resources management results). The data was analyzed by employing 324 employee survey slopes, and the study sample consisted of multiple. The results showed that organizational culture and employee empowerment from the practice of TQM have a strong impact on employee living perception and communication.

Ijaz \& et.al (2012), aimed at studying the relationship between TQM and RDA practices. A study of staff working in six institutions, 243 employees in Pakistani organizations. The study was conducted on the employee performance and job satisfaction that TQM showed. The results of the study showed the positive and significant impact of practices resulting in greater commitment, motivation and reduced absence.

Nayak (2012) aimed at understanding the impact of TQM practices in the corporate sector in the southern Gujarat region. The study was conducted on a sample of 250 employees in India to collect data through the questionnaire. The results of the study showed that employee participation is vital to success implementation of Total Quality Management. The results also show that companies are planning a growth process which is based on constant innovation to provide customer satisfaction, improvements and knowledge creation to provide customers satisfaction.

Saman Yapa (2012), the purpose of his paper is to report the results of an investigation on the use of total quality management (TQM) tools, techniques and concepts among Sri Lankan service organizations. The results will provide information to the practitioners to implement TQM in their organizations and to academics to design courses in TQM.

Alawad (2011) study of the processing of poultry in the Kingdom of Saudi Arabia. The study was conducted on a selected sample of three poultry processing plants. Data were collected using the questionnaire. The study showed that TQM practices have a positive impact on the productivity of poultry processing plants.

Naser A. Aboyassin, Marwan Alnsour, Moayyad Alkloub (2011), study provides useful information and impartial advice for managers in the insurance business in Jordan. It also suggests new business practices for the sector. 
Faisal Talib, Zillur Rahman, M.N. Qureshi (2011), the analysis revealed the significance and usage of TQM in Indian service industries. The results also suggested that use of TQM models and frameworks, and continuously improving the ongoing TQM practices. AlShobaki, Fouad \& Al-Bashir, (2010) who found that the level of TQM implementation in the Jordanian banks is moderate and its implementation led to increased productivity and ability to compete in global markets.

Abdullah Ahmed Abdullah Da'as (2010) describes in their study that aimed to determine the impact of the overall quality improvement in the financial performance management, through practical study in a sample of Jordan commercial banks, and this study came to a set of results a significant differences correlation relationships were found between each of the overall quality and improve financial performance in the Jordan commercial banks management dimensions. As well as, the presence of statistically significant differences between the averages of the look of the workers in the commercial banks to the levels of the application of TQM dimensions differences back to the number of courses in the field of TQM and in favor of those with more than one course in the field of TQM, while there were no such differences are attributable to other demographic variables.

Aktham Al-Sarayreh (2009), the practices of TQM strategies in services organizations, which is the stage next to the implementation of the basics of TQM in business organizations, taking into account that previous studies focused on the extent of implementation of TQM in business organizations. Therefore, this study is pursuing the assessment of TQM implementation in banking sector in Jordan and it's affected on Job Performance.

\section{The Concept \& Definitions of Total Quality Management (TQM):}

Haddad has offered numerous definitions for quality out of them: - "Quality is the physical or non-physical characteristics which constitute the fundamental nature of something, or is one of the characteristics of a thing (Haddad, 2009).

The British Quality Association (BQA) offered three alternative definitions of TQM (Wilkinson, A., Redman, T., Snape, E. and Marching ton M,1998). The first focuses on the so called "soft" qualitative characteristics, found in the work of US consultants such as customer orientation, culture of excellence, removal of performance barriers, teamwork, training and employee participation. Here TQM is consistent with open management styles, delegated responsibility and increased autonomy to staff. The second BQA definition emphasizes the production aspects such as systematic measurement and control of work, setting standards of performance and using statistical procedures to assess quality. This is the "hard" production/operations management type of view, which arguably involves less discretion for employees. The third definition is a mixture of "hard" and "soft", comprising three features: an obsession with quality; the need for a scientific approach; and the view that all employees are to be involved in this process.

AL-Aqeeli defined quality as " the organization's production of a commodity or provide a high quality service through which to meet the needs and desires of its customers that is consistent with their expectations and achieve satisfaction and happiness". (Al-Aqeeli: 2001), thus, quality from the point of view of overall quality could be looked upon as accuracy, perfection, discrimination and integrity.

TQM is an integrated administrative system that requires a culture of organizational culture The participation of employees at all administrative levels in the process of continuous improvement of quality, quality training and quality training in all stages of work, relying on efficient information systems and availability of communications, in order to improve the quality of banking services provided, in order to achieve or exceed the expectations of customers (internal and external) and achieve the profitability and professionalism of the bank (Al-Sarayreh, 2009). 
TQM a philosophy or a set of ideas translated into the form of a system running according to an administrative strategy that follows the bank to achieve a high quality that touches all activities, jobs, etc., through the implementation of continuous improvement processes, and coordination of all geodes to achieve customer satisfaction and employee (Abdallah,2013)

\section{Elements (Principles) of TQM}

Base on the work of (Shahin, Abandi, \& Javadi, 2011) \& (Suri, 2005; Mathur, 2011; Huai, 2012; Abdallah, 2013) and Tari, J. J. (2005) the following are quality management principles:

\section{1 - Customer Focus}

The customer is satisfied by the principle of satisfaction of both the external customer and the internal customer. The purpose of the customer or client is limited to the quality management philosophy of the external customers of the bank only, but the customer can accommodate the internal customers in the various departments and departments within the bank and gain satisfaction and loyalty (Shahin, Abandi, \& Javadi, 2011).

\section{2 - Top Management Commitment}

The quality of strategic planning is considered one of the most important principles of quality management. It includes a long view of the quality of the bank. It requires time, appropriate balance and careful planning. The first steps begin with the formation of a committee or a team to participate in. In the membership of representatives from all business units in the bank, and is concerned with the development of quality policies that must focus on increasing customer satisfaction. The implementation of rigorous quality management is a strategic approach taken by the blind management, and is dependent on the management of blindness and material and moral support (Abdallah, 2013).

\section{3 - Continuous Improvement}

Continuous improvement is the main tool for achieving the highest level of performance by adapting an enduring effort to improve the quality of process, product, services and people. (Mathur, 2011) Continuous improvements of all operations, activities, and aspects are the core of TQM, leading to customer satisfaction.

\section{4- Training}

Individual training plan, training for job requirements, general training program (Tari. J. J, 2005).

\section{5- Employee Engagement}

Employee engagement considered very essential for continuous improvement, according to (Mathur, 2011).

\section{6- Collective co-operation instead of competition}

The firm quality management adopts the process of collective cooperation in different administrative levels and between each other "within the institution rather than the competition, where the departments and sections are able through cooperation to know the needs of departments and other sections in order to support the process of improvement.

The cooperation between the managers and the employees can be achieved through the addition of the effects in the system of reward and performance evaluation, as well as encouraging the work as a 
supportive tool for continuous improvement, in addition to confining others and giving confidence to the people (Huai, 2012).

\section{Financial Performance}

Financial performance considered as a measure set for the success of organizations; organization lacking to the basic level required, endanger its existence and continuation, so banks focused on financial performance in order to provide appropriate banking environment and to address the many challenges posed by technological developments and information; and for the purpose of achieving the goal of this research, was necessary to recognize the reality of the financial performance \& job performance of Sudanese French Bank and that through the study and analysis of the indicators related to the performance in the bank in order to evaluate the activities and services provided, through the results reflected in these indicators, and to achieve this goal will study and analyze the profitability and liquidity ratios.

\section{Study Variables}

\section{Independent Variables}

\section{Elements of the Overall Quality Management}

1. Top management.

2. Continuous Improvement.

3. Training.

4. Employee Engagement.

Dependent Variables

-The Financial Performance

1. Profitability Ratio.

2. Liquidity Ratio.

- Job Performance

\section{Study Hypotheses}

\section{Main Hypotheses}

Hypothesis 1: "There is no significant statistically effect of Total Quality Management dimensions (elements) on financial performance in Sudanese French Bank-Khartoum State-Sudan".

Hypothesis 2: "There is no significant statistically effect of Total Quality Management dimensions (elements) on Job performance in Sudanese French Bank-Khartoum State-Sudan".

\section{This Subdivided into the following sub-hypotheses}

The first sub-hypothesis: No significant statistically effect relationship between TQM dimensions (Top management commitment, continuous improvement, Training, Employees engagement) and the Profitability Ratios in Sudanese French Bank.

The second sub-hypothesis: No significant statistically effect relationship between TQM dimensions (Top management commitment, continuous improvement, Training, Employees engagement) and Liquidity Ratios in Sudanese French Bank. 


\section{The Study Population and Sample:}

The study population are all workers in Sudanese French Bank, the workers has been selected in Sudanese French Bank- Khartoum State, where the study sample consisted of 120 employees in Sudanese French Bank- Khartoum State from all the levels. The distribution of respondents depending on demographic variables: gender, age, and educational qualification, length of service, job level, and number of training courses in the field of TQM.

1) The highest percentage proportion of the distribution from the sample depending on the variable sex was $(62.5 \%)$ to the category (male), while it reached the lowest percentage $(37.5 \%)$ to the female category.

2) The highest percentage proportion of the distribution from the sample depending on the variable age was $(52.5 \%)$ of the category (25-35), while it reached the lowest percentage $(9.2 \%)$ to the category (less than 25).

3) The highest percentage proportion of the distribution from the sample depending on the variable educational qualifications was $(80.0 \%)$ to the category (BA), while it reached the lowest percentage $(2.5 \%)$ to the category $(\mathrm{PhD})$.

4) The highest percentage proportion of the distribution from the sample depending on the variable length of service $(40.0 \%)$ to the category (5-10 years), while it reached the lowest percentage $(10.0 \%)$ to the category (11-15).

5) The highest percentage proportion of the distribution from the sample depending on the variable number of training courses (65\%) to the category (one course), while it reached the lowest percentage (35\%) to the category (no course).

6) The highest percentage proportion of the distribution from the sample depending on the variable job level (80\%) low management level. While the lowest percentage (5\%) to the top management level.

\section{Statistical Analysis Results}

This section includes the display and analysis of the data accumulated by the researcher through the questionnaire that was distributed to respondents of all individuals; in this study the "effect of total quality management on the financial \& Job performance (A field study in Sudanese French Bank)". Followings are the results:

\section{Results related to Arithmetic Averages}

\section{Averages and standard deviations extracted for the answers were presented below:}

1. The Board of Directors of the bank confirms to adhere to the specified quality program in advance, the mean is (4.36) and the SD is (0.56).

2. Heads of departments in the bank interested to pursue quality program effectively and induce staff to abide by it, its mean (3.89) and its SD (0.84).

3. Top management of the bank holds for the quality constantly, the statement mean (4.21) and its SD (0.62).

4. Top management adopts strategic objectives of quality depending on the needs and desires of depositors and borrowers and beneficiaries, mean (3.99) and SD (0.69).

5. Top management of the bank is interested to establish specialized courses, which aims to identify to the employees at all levels of the importance of quality and the events of the methods applied in this area, the mean is (4.01) and its SD is (0.90).

6. Total management's commitment to the philosophy of the overall quality as a whole, the mean is (4.08) and the SD is (0.50).

The arithmetic mean of the answers ranged between (3.89- 4.36); the highest was for the paragraph, "the Board of Directors of the Bank confirms to adhere to the specific quality program in advance" (4.36), and 
in the second place came the paragraph " the senior management of the Bank holds for the quality constantly" (4.21), and came in third place," top management of the bank to identify the importance of quality and the events of the methods applied in this area to the employees at all levels is interested to establish specialized courses" (4.08), and in fourth place came the paragraph "senior management adopts strategic objectives of quality depending on the needs and desires of depositors and borrowers and beneficiaries" (4.01); in fifth place came the paragraph "heads of departments in the bank interested to pursue quality program effectively and induce staff to abide by it" (3.89).

It is evident from the above results that the Sudanese French Bank management is committed to the philosophy of total quality because of the importance in achieving future success of the bank; and the reason for this may be due to the success of the overall quality management and the application of its methodology depends largely on the extent of convinced of the top management at the bank in its benefits and need to be applied in order to achieve continuous improvement in the quality of banking services offered by the bank.

Averages and standard deviations for the answers of "continuous improvement of banking operations"

1. Bank's administration is seeking to reduce the operational procedures of the bank regarding withdrawals and deposits; the mean is (4.09) and the SD (0.78).

2. Top management at the bank relies on new systems and methods to improve the performance and service, its mean (4.42) and its SD (0.61).

3. The bank has an information system that is interested in studying the market and economic changes, mean is (3.90) and SD is (0.70).

4. Reducing errors and financial gaps to the minimum is a basic of the bank's work, its mean is (4.37) an $\mathrm{SD}$ is $(0.72)$.

5. The bank adopts a program to reduce the time of service innovation cycle or current services, mean (3.93) and SD (0.86).

6. The area of continuous improvement of banking operations as a whole, the mean (4.11) and the SD (0.51).

As seen from the above table that the arithmetic mean of the answers respondents for the variables studied ranged between (3.93-4.42), the highest was to the paragraph "senior management at the bank relies on new systems and methods to improve the performance and service" (4:42), and in the second place came the paragraph " reducing errors and financial gaps to the minimum is a basics of the bank's work",(4.34), and came in third place, "The bank's administration is seeking to reduce the operational procedures of the bank regarding withdrawals and deposits ",(4.11), and in fourth place came the paragraph "The bank has an Information that is interested in studying the market and economic changes" (3.90), and came in fifth and last place the paragraph " The bank adopts a program to reduce the time of service innovation cycle or current services" (3.93), The arithmetic average for this axis as a whole was (4.15). Is clear from the above results the importance of continuous improvement and innovation in banking operations in terms of delivery and development, so it required by the bank management.

\section{Averages and standard deviations for the answers for "participation of workers"}

1. Mainly my boss gives me room to take advantage of the experience and follow his example, its mean (4.13) and the SD (0.82).

2. My boss guides me when asking him to solve a problem related to the Work; the mean is (4.30) and SD (0.79).

3. Bank's management participates in decisions making process in the department where I work, mean is (4.17) and its SD (0.70). 
4. The spirit of cooperation prevails between staff in different Departments in the bank, its mean (3.98) and its SD (0.89).

5. Top management encourages employees to work as a team, its mean (4.03) and its SD (0.84).

6. The area of participation of workers as a whole, the mean is (4.02) and the SD is (0.53).

The arithmetic mean of the answers respondents for the variables studied ranged between (3.98-4.30), the highest was to the paragraph " My boss guides me when asking him to solve a problem related to the work " (4.30), in the second place came the paragraph " Bank's management participates in decisions making process in the department where I work " (4.17), in third place came the "Mainly my boss gives me room to take advantage of the experience and follow his example" (4.13), in fourth place came the paragraph "Senior management encourages employees to work as a team"(4.03), in fifth and final axis paragraph was " The spirit of cooperation prevails between staff in different departments in the bank" (3.98); and the area of participation of workers as a whole was (4.02).

\section{Averages and standard deviations for the answers for "training"}

1. Training programs in the bank aim to obtain a high level of quality, mean is (4.07) and SD is (0.77).

2. Training programs aim to emphasize the importance of quality in banking services, its mean (4.15) and its SD (0.79).

3. The administration develops programs for training in a scientific and thoughtful ways to serve the philosophy of total quality management, mean is (3.93) and SD is (0.68).

4. The bank administration allocates the necessary training Resources, the mean is (3.90) and SD (0.76).

5. Training programs at the bank aim to prevent mistakes the mean (3.92) and the $\mathrm{SD}(0.80)$.

6. The area of training as a whole, mean is (4.01) and the SD (0.55).

Encouragement of the top management to workers to work as a team reduces time and resources thus, achieve profitability to the bank" a mean (3.93), while in the last place was " The banking information system applied in the bank leads to achieve a leading competitive therefore, achieve a profitability to the bank " a mean (3.90), the arithmetic average of the instrument as a whole was of (4.05).

\section{Averages and standard deviations for the answers for "liquidity ratio of the bank"}

1. The bank management measure quality program in all departments working on achieving financial liquidity for the bank, its mean (4.03) and its SD (0.65).

2. Banking information system adopted in the bank leads to achieve a good competitive position thus, achieve liquidity for the bank, the mean is (4.03) and the SD is (0.65).

3. Participation of the bank's management to the personnel in decision-making process reduces the risk and thus, achieves liquidity for the bank, its mean is (4.17) and its SD is (0.74).

4. Continuous improvement in existing banking operations contribute to accuracy and faster in delivery of services on time thus, achieving financial liquidity for the bank, mean is (4.27) and SD is (0.67).

5. Top management of the bank's commitment to the philosophy of total quality leads to achieve financial liquidity for the bank, its mean (4.06) and its SD (0.62).

6. Top management of the bank commitment to the philosophy of total quality in achieving liquidity for the bank, mean (4.14) and SD (0.74).

7. Encouragements of the senior management to employees to work as a team reduces the time and resources and thus achieve financial liquidity for the bank, mean is (4.12) and its SD is (0.72).

8. Continuous improvement in existing banking operation system contributes in flexibility in responses to the needs of clients thus; achieve financial liquidity for the bank, the mean (4.24) and the SD (0.68).

9. The area of liquidity ratio of the bank as a whole, its mean (4.04) and its SD (0.66).

The arithmetic mean of the answers of the respondents for the variables studied ranged between (4.044.27), came in the first place the paragraph "Continuous improvement in existing banking operations 
contribute to accuracy and faster in delivery of services on time thus, achieving financial liquidity for the bank ", with a mean (4.27), and came in second place, "continuous improvement in existing banking operation system contribute in flexibility in responses to the needs of clients thus, achieve financial liquidity for the bank " a mean (4.24), and in the third place " Participation of the bank's management to the personnel in decision-making process reduces the risk and thus, achieve liquidity for the bank " a mean (4.17), In fourth place," The commitment of senior management of the bank to the philosophy of total quality leads to achieve profitability for the bank" a mean (4.14), and in the fifth place was the paragraph"

Encouragements of the senior management to employees to work as a team reduces the time and resources and thus, achieve financial liquidity for the bank " a mean (4.12), while in sixth place, "senior management of the bank's commitment to the philosophy of total quality leads to achieve financial liquidity for the bank " a mean (4.08), and in seventh place "Banking information system adopted in the bank leads to achieve a good competitive position thus, achieve liquidity for the bank " a mean (4.06), while in the last place was " The bank management measure quality program in all departments working on achieving financial liquidity for the bank " a mean (4.04), the arithmetic average of the instrument as a whole was of (4.03).

\section{The results concerning the test of hypotheses of the study:}

Main hypothesis 1: There is a statistically significant effect at the significance for total quality management on the financial performance a field study in the Sudanese French Bank.

\section{Subdivided into the following sub-hypotheses:}

First sub- hypothesis: There is a statistically significant effect at the significance for total quality management on the ratio of the profitability of the Bank a field study in the Sudanese French Bank. To validate this hypothesis multiple regressions was applied to examine the impact of the dimensions of $\mathrm{TQM}$ on the ratio of profitability equation.

The results of the application of multiple regression equation to study the impact of the dimensions of total quality management on profitability ratio show that:

1) There is a statistically significant effect at the significance level $(\alpha \leq 0.05)$ for the commitment of the management to the philosophy of total quality management on profitability ratio, where values of ( $\beta$, T) reached $(0.36,3.06)$, respectively, a statistically significant values.

2) There is a statistically significant effect at the significance level $(\alpha \leq 0.05)$ for the continuous of banking operation on profitability ratio, where values of $(\beta, T)$ reached $(0.27,2.27)$, respectively, a statistically significant values.

3) There is no statistically significant effect at the significance level $(\alpha \leq 0.05)$ for the participation of workers on the ratio of profitability, where values of $(\beta, T)$ reached $(0.14,1.32)$, respectively, values which are not statistically significant.

4) There is no statistically significant effect at the significance level $(\alpha \leq 0.05)$ for the training on the ratio of profitability, where values of $(\beta, T)$ reached $(0.08,0.82)$, respectively, values which are not statistically significant.

5) There is a statistically significant effect at the significance level $(\alpha \leq 0.05)$ for the dimensions of the overall quality management as a whole on profitability ratio, as the value of the correlation coefficient (R) was (0.76), a value statistically significant which indicates the degree of correlation between the independent variables and dependent variables, and the value of (R-square) was (0.58), a statistically significant value explains the ability of Total Quality Management in influencing the rate of profitability, and the test value $(\mathrm{F})$ was of (14.08) a statistical significant value of $(0.00)$, a statistically significant value at the significance level $(\alpha \leq 0.05)$ indicate of a statistically significant relationship between the independent variable and dependent variables, therefore, accepts the alternative hypothesis and rejects formula zero. 
Second sub- hypothesis: There is a statistically significant effect at the significance level $(\alpha=0.05)$ for total quality management on the liquidity ratio of the bank a field study in the Sudanese French Bank. To validate this hypothesis multiple regression equation has been applied to examine the impact of the dimensions of TQM on the liquidity ratio of the bank.

The results of the application of multiple regression equation to study the impact of the dimensions of TQM dimensions on the liquidity ratio of the bank show that:

1. There is a statistically significant effect at the significance level $(\alpha \leq 0.05)$ for the commitment of the management to the philosophy of total quality management on the liquidity ratio of the bank, where values of $(\beta, T)$ reached $(0.49,3.41)$, respectively, a statistically significant values.

2. There is no statistically significant effect at the significance level $(\alpha \leq 0.05)$ for the continuous of banking operation on the liquidity ratio of the bank, where values of $(\beta, T)$ reached $(0.31,2.08)$, respectively, which are not statistically significant values.

3. There is no statistically significant effect at the significance level $(\alpha \leq 0.05)$ for the participation of workers on the liquidity ratio of the bank, where values of $(\beta, T)$ reached $(0.14,1.17)$, respectively, values which are not statistically significant.

4. There is no statistically significant effect at the significance level $(\alpha \leq 0.05)$ for the education and training on the liquidity ratio of the bank, where values of $(\beta, T)$ reached $(0.06,0.36)$, respectively, values which are not statistically significant.

5. There is a statistically significant effect at the significance level $(\alpha \leq 0.05)$ for the dimensions of the overall quality management as a whole on the liquidity ratio of the bank, as the value of the correlation coefficient $(\mathrm{R})$ was $(0.68)$, a value statistically significant which indicates the degree of correlation between the independent variables and dependent variables, and the value of (R-square) was (0.46), a statistically significant value explains the ability of Total Quality Management in influencing the liquidity ratio of the bank, and the test value $(F)$ was of (8.92) a statistical significant value of $(0.00)$, a statistically significant value at the significance level $(\alpha \leq 0.05)$ indicate of a statistically significant relationship between the independent variable and dependent variables, therefore, accepts the alternative hypothesis and rejects formula zero.

Main Hypothesis 2: "There is no significant statistically effect of Total Quality Management dimensions (elements) on job performance in Sudanese French Bank -Khartoum State -Sudan". To validate the main second hypothesis, the multiple regression equation has been applied to examine the impact of the dimensions (elements) of TQM on job performance.

The results of the application of multiple regression equation to study the impact of the dimensions (elements) of TQM dimensions on the job performance show that:

1. There is a statistically significant effect at the significance level $(\alpha \leq 0.05)$ for the commitment of the management to the philosophy of total quality management on job performance, where values of $(\beta, T)$ reached $(0.47,5.59)$, respectively, a statistically significant values.

2. There is a statistically significant effect at the significance level $(\alpha \leq 0.05)$ for the continuous of banking operation on job performance, where values of $(\beta, T)$ reached $(0.34,3.43)$, respectively, which is a statistically significant values.

3. There is no statistically significant effect at the significance level $(\alpha \leq 0.05)$ for the participation of workers on job performance, where values of $(\beta, T)$ reached $(0.04,0.32)$, respectively, values which are not statistically significant.

4. There is no statistically significant effect at the significance level $(\alpha \leq 0.05)$ for the training on job performance, where values of $(\beta, T)$ reached $(0.12,1.27)$, respectively, values which are not statistically significant.

5. There is a statistically significant effect at the significance level $(\alpha \leq 0.05)$ for the dimensions (elements) of the overall quality management as a whole on job performance, as the value of the 
correlation coefficient $(\mathrm{R})$ was $(0.75)$, a value statistically significant which indicates the degree of correlation between the independent variables and dependent variables, and the value of (R-square) was (0.56), a statistically significant value explains the ability of Total Quality Management in influencing the job performance, and the test value $(F)$ was of (31.03) a statistical significant value of (0.00), a statistically significant value at the significance level $\quad(\alpha \leq 0.05)$ indicate of a statistically significant relationship between the independent variable and dependent variables, therefore, accepts the alternative hypothesis and rejects formula zero.

\section{Conclusion}

Through the study and analysis of the dimensions of Total Quality Management, and its impact on improving financial performance in the Sudanese French Bank, and after a statistical analysis of the relationship between TQM dimensions and their impact on improving financial performance in the bank this study conclusion, including:

1. Recognition of workers to the importance of the overall quality elements (support and commitment of senior management philosophy of total quality, continuous improvement, education and training for workers, the participation of employees, customer satisfaction) in improving the financial performance of the Sudanese French Bank.

2. Findings of this study indicate that there is a statistically significant relationship between the overall quality and financial performance elements in the Sudanese French Bank.

3. There is a statistically significant effect of TQM on liquidity ratio of the Sudanese French Bank.

4. There is a statistically significant effect of TQM on the profitability ratio in the Sudanese French Bank.

5. Double participation of workers in the process of improving financial performance in the Sudanese French Bank.

6. There is no statistically significant effect for education and training in the process of improving financial performance in the Sudanese French Bank.

\section{Recommendations}

1. The study recommends for the need to involve employees in the application of total quality management, for the study concluded the importance of comprehensive quality elements and their impact on improving financial performance.

2. The study recommends for the need to hold consecutive training courses for employees in the Sudanese French Bank about the overall quality elements, and its impact on improving financial performance.

3. The study recommends focusing on the process of training in the Sudanese French Bank, because of its impact on improving financial performance.

\section{References}

Abd Al- Mouty ,Zaki \& Abu Zyeada.The effect of time and total quality management on the job performance: A field study on samples of Palestinian Commercial Banks, Jordan Journal of Business Administration , 8(1).(Arabic source ), (2012).

Abdullah Ahmed Abdullah Da'as, Total quality management (TQM) and its effect on improving the financial performance-An applied study using samples of Jordanian commercial banks, Management Science Studies, 37. (Arabic source), 2010.

Abla S.S Tahtamouni \& others, Factors affecting Total Quality management (TQM) implementation in Jordanian Commercial Banks, Interdisciplinary Journal of Contemporary Research in Business , 2013.

Agrawal \& Shukla, 2012. Aggarwal, Techniques of performance appraisal-a review, International Journal of Engineering and Advanced Technology (IJEAT), (2013). 
Ameen Al-basheer and others, 2015, The Impact of Management Information Systems on the Financial Performance of Islamic Banks in Jordan-Jordan Islamic Bank: A Case Study, International Journal of Business and Management; Vol. 10, No. 10.

Al Aqeeli, Omar Wasfee, (2001), Introduction to the intergrated methodology for TQM (point of view), Dar Wael for publication, Amman, Jordan.

Al-Daas,Abdullah A.(2010) .Total quality management (TQM) and its effect on improving the financial performance-An applied study using samples of Jordanian commercial banks, Management Science Studies, 37. (Arabic source).

Al-Sarayreh ,Aktham Abdelmajeed .The effect of total quality management (TQM) implementation in Jordanian banking sector on job performance, Journal of Management and Economics, 2009.

Al-Shobaki Salman D., Fouad Rami H. \& Al-Bashir Adnan (2010). The implementation of total quality management (TQM) for the banking sector in Jordan, Jordan Journal of Mechanical and Industrial Engineering, 4(2), $304-313$.

Alwadi, M. H. \& Mohamed Samhan, H. (2011). The extent of total quality management in Jordanian banks. Arab Journal of Economic and Administrative Sciences, (3), 213.

Faisal Talib, Zillur Rahman, M.N. Qureshi,2011, "Total quality management and service quality: an exploratory study of management practices and barriers in service industries", International Journal of Services and Operations Management (IJSOM), Inderscience, UK, Vol.10, No.1, pp. 94-118.

Hadad, Awatef Ibrahim, (2009), Total Quality Management, Dar Al Feker for puplishers and distributors, Amman, Jordan.

Hilda Ghaleb Madanat, Anis S. Khasawneh, Impact of total quality management implementation on effectiveness of human resource management in the Jordanian Banking Sector from employee's perspective, Academy of Strategic Management Journal, Volume 16, Number 1,2017.

Huai ,Jinmei (2012). Apply TQM to e-government outsourcing management", Physics Procedia ,24, 1159 $-1165$.

Ijaz \& et.al, 2012, the relationship between TQM and RDA practices in Pakistan organizations.

Jain ,Ankur \& Gupta, S. L. ( 2012). Effects of total quality management on perceptual human resource management outcomes in software industry in India. Research in Business and Management, 1(2), 2335.

Jureviciee, D. \& Skvarciany, V. (2013). Small and medium-sized companies' satisfaction with banks, service quality. European Scientific Journal December /Special/edition, 1, 32-36.

(Kartha, C. P. 2004), A comparison of ISO 9000: 2000 quality system standards, TQM Magazine, 16, 331 340.

Kasim Randeree, Ashish Mahal, Anjli Narwani,2012," A business continuity management maturity model for the UAE banking sector", Business Process Management Journal. Volume: 18 Issue: 3.

Mathur, Vipin (2011).Principles of total quality management, (1st ed.), Published by G.S.Rawat for Cyber Tech Publications, Newdelhi, Indea.

Naser A. Aboyassin, Marwan Alnsour, Moayyad Alkloub,2011,' Achieving total quality management using knowledge management practices: A field study at the Jordanian insurance sector", International Journal of Commerce and Management. Volume: 21 Issue: 4.

Nayak, 2012, The impact of TQM practices in the corporate sector in the southern Gujarat region, International Journal of Information, Business and Management, Vol. 3, No.2.

Saman Yapa, 2012," Total quality management in Sri Lankan service organizations", The TQM Journal Volume: 24 Issue: 6.

Shahin , Arash, Abandi ,Ali Asghar \& Javadi ,Mohammad Hosein Moshref (2011). Analyzing the Relationship between Customer Satisfaction and Loyalty in the Software Industry - With a Case Study in Isfahan System Group, International Journal of Business and Social Science, 2( 23).

Suri ,kulneet (2005).Total quality management principles and practices ,tools and techniques ,(2nd ed.), Sanjeev Kumar Kataria, Delhi.

Tari, J. J. (2005). Components of successful total quality management. TQM Magazine,17.

Terziovskim, M. \& Samson, D. (2000), Relationship between TQM Strategy and Organizational Performance, The TQM Magazine, 12(2), 144-148. 
Temtime, Z., \& Solomon, G. H. (2002). Total quality management and the planning behavior of SMEs in developing economies. TQM Magazine, 14, 181-191.

Wilkinson, A., Redman, T., Snape, E. and Marchington M., (1998), Managing with Total Quality Management: Theory and Practice, Hong Kong: Macmillan Press Ltd.
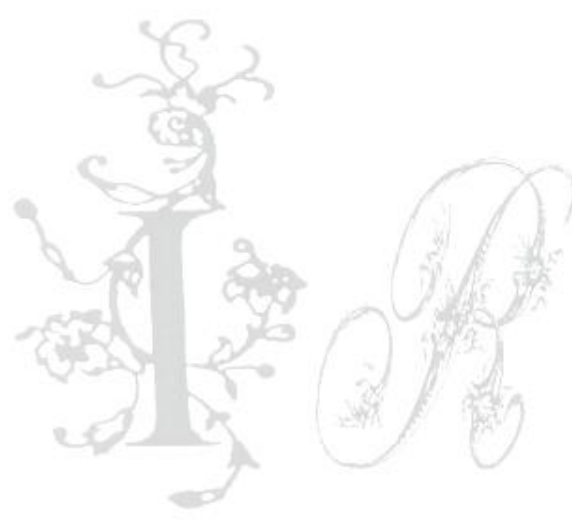